\section{NEW RECORDS OF PLANTS FROM RAJASTHAN}

\section{Satish Kumar Sharma ${ }^{1}$, S.S. Katewa ${ }^{2}$ and Chhaya Bhatnagar ${ }^{3}$}

${ }^{1}$ Foundation for Ecological Security, 18, New Ahinsapuri, Fatehpura, Udaipur, Rajasthan 313001, India

${ }^{2}$ Associate Professor, ${ }^{3}$ Assistant Professor, Department of Botany, M.B. College, M.L.S. University, Udaipur, Rajasthan 313001, India Email: ${ }^{1}$ fes.udaipur@gmail.com

The forests of southern Rajasthan, especially Mount Abu, Phulwari, Sitamata and Kumbhalgarh wildlife sanctuaries have great floral diversity according them 'mega floral diversity spots' of Rajasthan. The valleys and stream banks of these protected areas are rich in terrestrial orchids, tuberous plants, climbers and lianas as well as pteridophytic and bryophytic flora. During botanical surveys, conducted from 2001 to 2004, many new plant specimens were collected from many sites of southern and eastern Rajasthan, which are new to the flora of Rajasthan. A list of newly recorded species is given in Table 1 .

Literature review on the flora of Rajasthan (Sharma \& Tiagi, 1979; Shetty \& Pandey, 1983; Singh, 1983; Shetty \& Singh, 1987, 1991, 1993; Bhandari, 1990) revealed that Tacca leontopetaloides, Stephania hernandilolia, Crinum latifolium and Costus speciosus are not included in any of the state's Floras. Hence these species are new records for Rajasthan and worth publishing. According to Shetty and Singh (1991), Peperomia pellucida is a native of South America, naturalized in many parts of India including Rajasthan. It was collected from Jodhpur by Dr. Bhandari (Shetty \& Singh, 1991). Since there is no dense forest in Jodhpur, it was perhaps collected from some garden found as a weed, and not from the forest. In Sitamata Wildlife Sanctuary, it is seen growing as ground flora near Valmiki Ashram under the dense shade of various trees. Thus it is the first report of the occurrence of this introduced invasive species in the wild in Rajasthan.

Nymphaea rubra is quite similar to $N$. pubescens and the latter is common in ponds of southern Rajasthan. The leaves, petioles, petals, stamens, fruits and fruit-stalk of $N$. rubra are red in colour (Venu et al., 2003). N. rubra is found in many ponds of Banswara district and is seen growing with $N$. pubescens. Devotees offering flowers in the many temples of Banswara probably could be the reason for the introduction of N. rubra to the area.

Two varieties of Jatropha gossypiifolia namely elegans and gossypiifolia are present in Rajasthan. Both the varieties have different colour pattern in their body parts (Pullaiah \& Chennaiah, 1997). Young leaves including petioles and glands are of dark purple in colour in Jatropa gossypiifolia var. elegans which is common everywhere, while green in J. gossypiifolia var. gossypiifolia. The nominate variety is rare in Rajasthan. So far it has been seen inside Kota city in moist pockets in southeastern Rajasthan and in Wakal river bed near Gau-Pipla village in Phulwari Wildlife Sanctuary in southern Rajasthan.

Table 1. New records of plants in the wild from Rajasthan

\begin{tabular}{|c|c|c|c|c|c|c|}
\hline & Name of Plants \& Family & $\begin{array}{l}\text { Phulwari WS (Dist. } \\
\text { Udaipur) }\end{array}$ & $\begin{array}{l}\text { Locality of occurrence v } \\
\text { Sitamata WS (Dist. } \\
\text { Udaipur \& Chittorgarh) }\end{array}$ & $\begin{array}{l}\text { with local status* }{ }^{*} \text { in } \\
\text { Kumbhalgarh WS } \\
\text { (Dist. Udaipur, } \\
\text { Rajsamand \& Pali) }\end{array}$ & $\begin{array}{l}\text { parenthesis) } \\
\text { Todgarh - Raoli WS } \\
\text { (Dist. Rajsamand, } \\
\text { Pali \& Ajmer) }\end{array}$ & $\begin{array}{l}\text { Other areas in } \\
\text { Rajasthan }\end{array}$ \\
\hline 1. & $\begin{array}{l}\text { Stephania hernandifolia Walp. } \\
\text { (Menispermaceae) }\end{array}$ & $\begin{array}{l}\text { Chuna Pani near } \\
\text { Mahad, Range Mamer } \\
\text { (R) }\end{array}$ & $\begin{array}{l}\text { Near Bhagi Baodi (West } \\
\text { of Forest Raod) (R) }\end{array}$ & - & - & - \\
\hline 2. & $\begin{array}{l}\text { Nymphaea rubra Roxb. ex } \\
\text { Andrews (Nymphaeaceae) }\end{array}$ & - & - & - & - & $\begin{array}{l}\text { Lodha and Kupda pond } \\
\text { (Banswara Dist.) (R) }\end{array}$ \\
\hline 3. & $\begin{array}{l}\text { Peperomia pellucida (L.) } \\
\text { H.B. \& K. (Piperaceae) }\end{array}$ & i & $\begin{array}{l}\text { Near Valmiki Ashram } \\
\text { (LC) }\end{array}$ & - & - & - \\
\hline 4. & $\begin{array}{l}\text { Costus speciosus (Koenig) } \\
\text { Smith (Zingiberaceae) }\end{array}$ & $\begin{array}{l}\text { 1. Gamdi-ki-Nal and } \\
\text { Dhedmariya, Range } \\
\text { Kotra (R) } \\
\text { 2. Bhildi Mata nallah and } \\
\text { Katawali Jer, Range } \\
\text { Panarwa (R) }\end{array}$ & $\begin{array}{l}\text { Along bank of stream fron } \\
\text { Bhagi Baodi to Sitamata } \\
\text { temple }(C) \\
\text { dd }\end{array}$ & & - & $\begin{array}{l}\text { Khokhariya-ki-Nal, } \\
\text { Kamalnath, Ladan and } \\
\text { Ramkunda Forest } \\
\text { Blocks** }\end{array}$ \\
\hline 5. & $\begin{array}{l}\text { Crinum latifolium L. } \\
\text { (Amaryllidaceae) }\end{array}$ & $\begin{array}{l}\text { Thala, Sarvam, } \\
\text { Katawali Jer, Mamer } \\
\text { (LC) }\end{array}$ & Arampura (LC) & $\begin{array}{l}\text { Areth Gate, Thandiberi, } \\
\text { Ranakankar, Bokhada, } \\
\text { Malgarh (LC) }\end{array}$ & $\begin{array}{l}\text { i,Kabar Data barrack, } \\
\text { Dhudleshwar Mahadeo } \\
\text { temple (LC) }\end{array}$ & $\begin{array}{l}\text { Som, Madri, Garanwas, } \\
\text { Kamalnath and Nal } \\
\text { Sandol Forest Blocks }\end{array}$ \\
\hline 6. & $\begin{array}{l}\text { Jatropha gossypiifolia L. } \\
\text { var. elegans (Pohl) Muell.-Arg. } \\
\text { (Euphorbiaceae) }\end{array}$ & Common (C) & Common (C) & Common (C) & Common (C) & Common (C) \\
\hline 7. & $\begin{array}{l}\text { Tacca leontopetaloides (L.) } \\
\text { Kuntze (Taccaceae) }\end{array}$ & $\begin{array}{l}\text { 1. Chuna Pani near } \\
\text { Mahad, Range Mamer } \\
\text { (R) } \\
\text { 2. Gamdi-ki-Nal, Range } \\
\text { Kotra (R) }\end{array}$ & $\begin{array}{l}\text { Near Valmiki Ashram, on } \\
\text { the way to Sitamata } \\
\text { temple }(R)\end{array}$ & - & - & $\begin{array}{l}\text { Kamalnath,Ramkunda, } \\
\text { Ladan, Khokhariya-ki- } \\
\text { Nal Forest Blocks }{ }^{* *}\end{array}$ \\
\hline
\end{tabular}

R - Rare; LC - Less Common; C - Common; A - Abundant; ${ }^{* *}$ All are under the jurisdiction of Udaipur (Central) Forest Division

(C) Zoo Outreach Organisation; www.zoosprint.org 


\section{REFERENCE}

Bhandari, M.M. (1990). Flora of the Indian Desert. MPS Reports, Jodhpur.

Pullaiah, T. and E. Chennaiah (1997). Flora of Andhra Pradesh (India) Vol. II. Scientific Publishers, Jodhpur, India.

Sharma, S. and B. Tiagi (1979). Flora of North-east Rajasthan. Kalyani Publishers, New Delhi \& Ludhiana.

Shetty, B.V. and R.P. Pandey (1983). Flora of Tonk District. Botanical Survey of India, Calcutta.

Shetty, B.V. and V. Singh (1987). Flora of Rajasthan Vol. I. Botanical Survey of India, Calcutta.

Shetty, B.V. and V. Singh (1991). Flora of Rajasthan Vol. II. Botanical Survey of India, Calcutta.

Shetty, B.V. and V. Singh (1993). Flora of Rajasthan Vol. III. Botanical Survey of India, Calcutta.

Singh, V. (1983). Flora of Banswara, Rajasthan. Botanical Survey of India, Calcutta.

Venu, P., T.J.S. Rajkumar and P. Daniel (2003). On the identity of and sterility of Nymphaea rubra Roxb. ex. Andrews (Nymphaeaceae). Rheedea 13(1\&2): 29-34.

\section{ACKNowledgement}

The first author (SKS) is very grateful to Jagdeesh Rao, Executive Director, Foundation for Ecological Security, Anand (Gujarat) for inspiration.

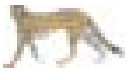

\section{Project on Invertebrate Assessment and Redlisting in South Asia}

\section{UCN SSC South Asian I nvertebrate Specialist Group / I nvertebrate Conservation and Information Network of South Asia.}

To fulfil one of the objectives of the South Asian Invertebrate Specialist Group we are in the process of compiling information of selected invertebrates for assessing risk of extinction. The objective is to prioritise the threatened species and to assign a status utilizing existing information with the intention of including highly threatened invertebrate species in the IUCN Red List of

Threatened Species as also work out conservation action plans either individually and for the taxonomic group.

For more information on this project and to be part of it, please write to

B.A. Daniel, T.N. Ananthakrishnan, Sanjay Molur and Sally Walker

South Asian Invertebrate Specialist Group

Zoo Outreach Organisation

29-1 Bharathi Colony, Peelamedu Coimbatore, Tamil Nadu 641004, India

Ph: +91 422 2561087, 2561743; Fx: 2563269 icinsa@vsnl.net, zooreach@vsnl.com
Mimusops eleNGI LINNAEUS (SAPOTACEAE), A NEW LARVAL FOOD PLANT OF EUPLOEA CORE CORE (CRAMER) (LEPIDOPTERA: NYMPHALIDAE)

\author{
Muhamed Jafer Palot ${ }^{1}$, V.C. Balakrishnan ${ }^{2}$ and \\ C. Radhakrishnan ${ }^{3}$
}

\section{1,3 Western Ghats Field Research Station, Zoological Survey of India, Kozhikode, Kerala 673002, India \\ ${ }^{2}$ Malabar Natural History Society, 17/548 A, I.G. Link Road, Kozhikode, Kerala 673004, India}

The Common Indian Crow, Euploea core core (Cramer) (Lepidoptera: Nymphalidae) is the commonest butterfly species found both in plains and hills in India. It is a polyphagous insect, known to lay eggs on several species belonging to families Moraceae, Asclepiadaceae and Apocynaceae plants such as Ficus benghalensis, F. racemosa, F. arnottiana, F. religiosa, F. elastica, Streblus asper, Cryptolepis elegans, C. buchanani, Hemidesmus indicus, Tylophora indica, Holarrhena pubescens, Ichnocarpus frutescens, Carissa carindas, Nerium odorum and N. oleander (Wynter-Blyth (1957); Gay et al. (1992); Kunte (2000); Jafer Palot and Radhakrishnan (2001)).

Mimusops elengi Linnaeus of the family Sapotaceae is a mediumsized tree found mostly in the forested areas of the Western Ghats and the sacred groves of Kerala. The tree is locally known as 'Elangi' and is noted for its gregarious flowering and fragrance.

During our study on the butterflies of Kerala, we observed the Common Indian Crow laying eggs on the leaves of Mimusops elengi. The butterfly completed its life cycle on the tree during the later part of southwest monsoon in August and September. The present record of Mimusops elengi Linnaeus is a new addition to the list of larval food plants of the Common Indian Crow Butterfly, Euploea core core (Cramer).

\section{REFERENCES}

Gay, T., I.D. Kehimkar and J.D. Punetha (1992). Common Butterflies of India. World Wide Fund for Nature-India, Bombay, 67pp.

Jafer Palot, M. and C. Radhakrishnan (2001). New larval food plants of Euploea core core (Cramer) (Nymphalidae: Lepidoptera: Insecta). Zoos' Print Journal 16(10): 614.

Kunte, K. (2000). Butterflies of Peninsular India. University Press (India) Limited, Hyderabad, 254pp.

Wynter-Blyth, M.A. (1957). Butterflies of the Indian region. Bombay Natural History Society, Bombay, 523pp.

\section{ACKNOWLEDGEMENTS}

The authors are grateful to Dr. J.R.B. Alfred, Director, Zoological Survey of India, Kolkata for facilities and encouragement and to Dr. A.K. Pradeep, Curator, Department of Botany, University of Calicut for confirming the identity of the plant species. 